\title{
Pengaruh pemberian plasma kaya trombosit terhadap ekspresi VEGF pada proses penutupan defek kalvaria menggunakan karbonat apatit
}

\author{
${ }^{1}$ Agung S. Pranoto, ${ }^{2}$ Maximillian Ch. Oley, ${ }^{2}$ Eko Prasetyo \\ ${ }^{1}$ PPDS Ilmu Bedah Fakultas Kedokteran Universitas Sam Ratulangi Manado \\ ${ }^{2}$ KSM RSUP Prof. Dr. R. D. Kandou Manado \\ Email: agungsindu_pranoto@yahoo.co.id
}

\begin{abstract}
To date, there are increasing brain injuries and calvaria defect due to traffic accidents. Angiogenesis plays a pivotal role in bone healing. This study was aimed to obtain the immunohistochemistry analysis of vascular endothelial growth factor (VEGF) expression in osteogenesis process with platelet rich plasma (PRP) and carbonate apatite scaffold in rat model. This was an experimental study with 24 male Wistar rats (Rattus norvegicus) as subjects. A 3-mm burrhole of calvaria was performed on each rat. The control group was applied with $0.1 \mathrm{ml}$ normal saline and the experimental group with $0.1 \mathrm{ml}$ PRP and carbonate apatite scaffold. The rats were sacrificed at 3 weeks later and the osteogenesis process were examined histologically focused on immunohistochemistry pattern of VEGF. The results showed that the defects applied with PRP and carbonate appatite scaffold showed earler osteoid tissue deposition with higher cell count for osteoblasts, osteocytes, and osteoclasts. Immunohistochemistry evaluation showed more VEGF expression in the PRP and carbonate apatite group compared with the normal saline group. The Mann-Whitney test showed significant difference between the two groups $(P<0.0001)$. Conclusion: Combination of PRP and carbonate appatite scaffold resulted in good closure of calvaria defect.
\end{abstract}

Keywords: VEGF, carbonate apatite scaffold, PRP

\begin{abstract}
Abstrak: Kecelakaan lalu-lintas meningkatkan kejadian cedera otak dan defek kalvaria. Angiogenesis berperan penting dalam proses penyembuhan tulang. Penelitian ini bertujuan untuk menganalisis ekspresi VEGF secara imunohistokimia dalam proses osteogenesis terhadap pemberian plasma kaya trombosit dan perancah karbonat apatit pada hewan coba tikus. Jenis penelitian ini ialah eksperimental menggunakan 24 tikus jantan strain Wistar (Rattus norvegicus) yang diberi perlakuan pembuatan defek kalvaria ukuran $3 \mathrm{~mm}$. Pada kelompok kontrol diberikan $0,1 \mathrm{ml} \mathrm{NaCl0,9 \%}$ dan pada kelompok perlakuan diberikan $0,1 \mathrm{ml}$ plasma kaya trombosit dan perancah karbonat apatit. Semua tikus diterminasi tiga minggu setelah perlakuan dan dilakukan pemeriksaan imunohistokimia ekspresi VEGF untuk mengevaluasi proses osteogenesis. Hasil penelitian mendapatkan pada kelompok defek yang diberikan plasma kaya trombosit dan perancah karbonat apatit menunjukkan pembentukan jaringan osteoid yang lebih cepat dengan jumlah osteoblas, osteosit, dan osteoklas yang lebih banyak. Pemeriksaan imunohistokimia untuk mengetahui ekspresi VEGF menunjukkan hasil yang lebih tinggi pada kelompok perlakuan dibandingkan pada kelompok kontrol. Uji MannWhitney menunjukkan perbedaan bermakna antara kedua kelompok $(P<0,0001)$. Simpulan: Pemberian plasma kaya trombosit dan perancah karbonat apatit memberikan hasil yang baik pada proses penutupan defek kalvaria.
\end{abstract}

Kata kunci: VEGF, perancah karbonat apatit, plasma kaya trombosit

Seiring dengan pertambahan jumlah kendaraan bermotor maka bertambah pula angka insiden fraktur tulang kalvaria dan cedera otak akibat kecelakaan lalu lintas. 
Masalah yang masih dihadapi setelah fraktur tulang kalvaria dan cedera otak ialah lama waktu penyembuhan yang menyebabkan pasien tidak bisa bekerja selama masa penyembuhan. Proses penyembuhan tulang sangat bergantung pada vaskularisasi. Untuk menunjang hal tersebut diperlukan pembentukan pembuluh darah baru (angiogenesis) yang memadai. Salah satu faktor yang dapat memengaruhi angiogenesis ialah vascular endothelial growth factor (VEGF) yang merupakan satu faktor pertumbuhan dalam platelet. ${ }^{1}$

Defek kalvaria adalah lubang yang terdapat pada kalvaria sehingga otak yang berada di bawah lubang tersebut menjadi kurang terlindungi karena hanya tertutup oleh lapisan kulit, jaringan ikat, aponeurosis, dan jaringan ikat longgar. Adanya defek kalvaria ini dapat terjadi pada cedera kepala akibat trauma dimana terjadi avulsi dari kalvaria. Hal ini juga dapat terjadi karena kelainan sejak lahir seperti meningiokel dan ensefalokel, namun defek kalvaria yang paling sering disebabkan karena cedera kepala yang membutuhkan suatu tindakan kraniektomi dekompresi. ${ }^{1}$

Plasma kaya trombosit adalah fraksi plasma darah dengan konsentrasi platelet 35 kali di atas nilai normal. ${ }^{1}$ Plasma kaya trombosit pertama kali digunakan tahun 1987 oleh Ferrari pada operasi jantung yang menggunakan autolog plasma kaya trombosit dan kemudian pada era tahun 2000 mulai dikembangkan untuk operasi kraniofasial, cedera muskuloskeletal dan luka kronis. ${ }^{2}$ Fennis menganalisis penggunaan plasma kaya trombosit terhadap pembentukan kalus dan penyambungan tulang kepala kelinci dan mendapatkan bahwa pemberian plasma kaya trombosit dapat mempercepat pertumbuhan kalus dan penyambungan tulang kepala. ${ }^{3}$ Monterio et al. ${ }^{4}$ mendapatkan hubungan positif antara plasma kaya trombosit terhadap penutupan defek kalvaria tikus namun beberapa penelitian antara lain oleh Miloro et al. ${ }^{5}$ dan van Bergen et al. ${ }^{6}$ menyatakan bahwa pemberian plasma kaya trombosit dengan atau tanpa tandur tulang tidak berbeda bermakna dalam meningkatkan pertumbuhan tulang. Sediaan plasma kaya trombosit dapat melepaskan beberapa jenis faktor pertumbuhan seperti platelet derived growth factor (PDFG), transforming growth factor-beta (TGF- $\beta$ ), insulin growth factor (IGF), vascular endothelial growth factor (VEGF), platelet derived endothelial cell growth factor (PDECGF), dan platelet derived angiogenesis factor (PDAF). ${ }^{7}$

Vascular endotheloal growth factor (VEGF) merupakan angiogenik dan termasuk agen dalam jalur angiopoetin. Pada pengaturan angiogenesis, VEGF berperan penting untuk regenerasi tulang. Sebagai regulator pada angiogenesis dan vaskulogenesis, VEGF berperan penting pada regenerasi jaringan. $^{7}$

Karbonat apatit merupakan suatu perancah yang dapat menginisiasi proses perkembangan sel-sel tulang dengan gugusan karbonat apatit $\mathrm{Ca}_{10}\left(\mathrm{CO}_{3}\right)_{6}(\mathrm{OH})_{2}$ dan rasio atom karbonat terhadap fosfat ialah 1,67 serta memiliki karakteristik seperti tulang manusia. Kemiripan ini disebabkan keberadaan 3 komponen utama penyusun tulang, yakni $\mathrm{Ca}, \mathrm{PO}_{4}$, dan $\mathrm{CO}_{3}$. Karbonat apatit mempunyai derajat kristalin yang rendah dan ukuran kristal yang lebih kecil jika dibandingkan dengan hidroksi apatit, oleh karena itu karbonat apatit memiliki osteokonduktivitas yang lebih tinggi. Karbonat apatit memiliki pori yang letaknya teratur dan ukurannya seragam sehingga proses remodeling menjadi lebih baik. ${ }^{8}$

Penelitian ini bertujuan untuk mengetahui apakah pemberian plasma kaya trombosit dapat meningkatkan ekspresi VEGF pada proses penutupan defek kalvaria menggunakan perancah karbonat apatit.

\section{METODE PENELITIAN}

Jenis penelitian ini ialah eksperimental laboratorik. Subyek penelitian terdiri dari 24 ekor tikus strain Wistar (Rattus norvegicus) berumur 20-22 minggu dengan berat 350-400 gr. Pada semua tikus dibuat defek kalvaria berdiameter $3 \mathrm{~mm}$. Kelompok perlakuan diberikan plasma 
kaya trombosit dan karbonat apatit pada defek tersebut sedangkan kelompok kontrol hanya diberikan normal salin. Saat pembuatan defek, dilakukan pemeriksaan imunohistokimia pada tulang kepala untuk mengetahui ekspresi VEGF awal. Pemeriksaan ekspresi VEGF akhir dilakukan setelah 3 minggu.

Data dianalisis secara statistik dengan analisis deskriptif dan analisis perbandingan 2 rerata. Uji kenormalan data digunakan uji Kolmogorov-Smirnov. Bila data kedua perlakuan menyebar normal maka digunakan uji t tidak berpasangan. Bila data satu atau kedua perlakuan tidak menyebar normal maka akan digunakan uji Mann Withney. Uji dikatakan bermakna bila $P<0,05$.

\section{HASIL PENELITIAN}

Gambaran histologik awal memperlihatkan sel-sel osteoprogenitor berbentuk spindel kecil dan osteosit yang tersebar merata (Gambar 1).

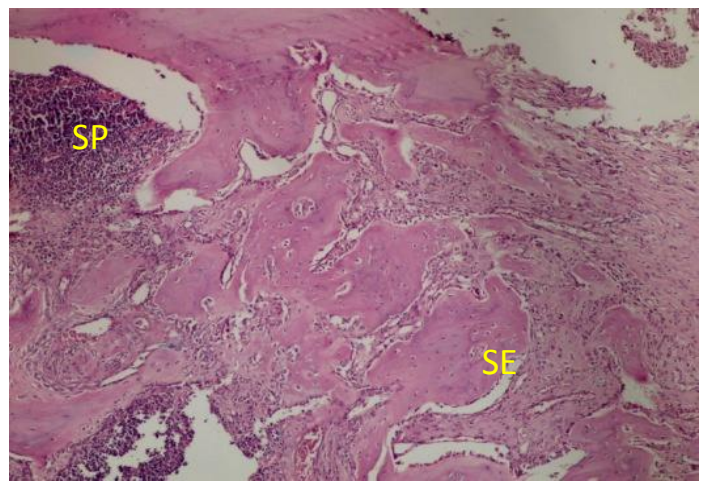

Gambar 1. Gambaran histologik kalvaria awal, tampak sel progenitor (SP) dan sel endotel (SE)

Pada gambaran histologik setelah 3 minggu juga terlihat osteosit dan sedikit sel-sel inflamasi disertai jaringan fibrosa dengan sel-sel progenitor dan fibroblas. Tampak bentukan trabekula tulang dikelilingi osteoblas yang akan menghasilkan unsur-unsur matriks organik tulang. Saat berada di dalam matriks maka sel-sel ini disebut osteosit. Pembuluh-pembuluh darah baru juga banyak ditemukan pada jaringan osteoid ini (Gambar 2).

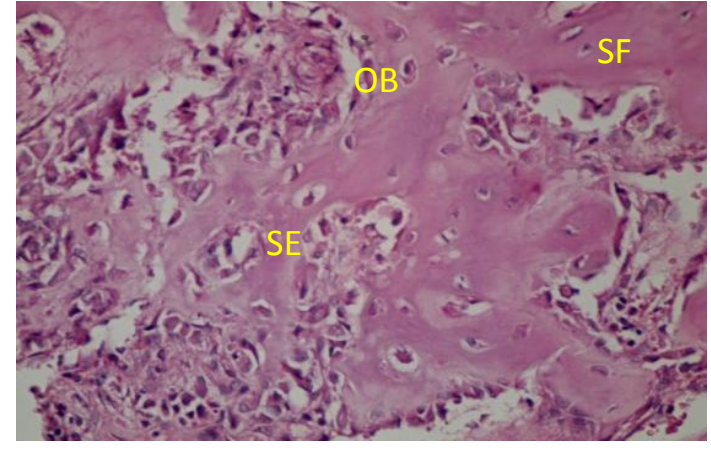

Gambar 2. Gambaran histologik akhir, tampak sel-sel fibroblas (SF), osteoblas (OB), dan endotel (SE)

Kelompok kontrol dan perlakuan menunjukkan gambaran histologik awal yang sama (Gambar 3) sedangkan gambaran histologik setelah 3 minggu menunjukkan perbedaan jumlah sel-sel yang mengekspresikan VEGF (ditunjukkan oleh warna kecoklatan) pada kedua kelompok, yaitu lebih banyak pada kelompok perlakuan (Gambar 4 dan 5).

Hasil pemeriksaan imunohistokimia ekspresi VEGF kedua kelompok dianalisis secara statistik dengan analisis deskriptif dan analisis perbandingan 2 rerata (Tabel 1). Uji kenormalan data Kolgomorov-Smirnov, mendapatkan data VEGF awal semuanya tidak menyebar normal $(P<0,05)$, dan data VEGF akhir kelompok kontrol tidak menyebar normal $(P<0,05)$.

Tabel 1. Ekspresi VEGF pada kelompok kontrol dan perlakuan

\begin{tabular}{ccc}
\hline No & Kontrol & Perlakuan \\
\cline { 2 - 3 } & $\begin{array}{c}\text { Ekspresi VEGF } \\
\text { awal/akhir }(\%)\end{array}$ & $\begin{array}{c}\text { Ekspresi VEGF } \\
\text { awal/akhir (\%) }\end{array}$ \\
\hline 1 & $5 / 20$ & $5 / 70$ \\
2 & $5 / 20$ & $5 / 60$ \\
3 & $5 / 20$ & $10 / 90$ \\
4 & $10 / 40$ & $5 / 80$ \\
5 & $5 / 30$ & $5 / 80$ \\
6 & $10 / 30$ & $5 / 90$ \\
7 & $10 / 30$ & $10 / 90$ \\
8 & $5 / 20$ & $5 / 80$ \\
9 & $5 / 40$ & $5 / 90$ \\
10 & $5 / 20$ & $5 / 80$ \\
11 & $5 / 30$ & $5 / 70$ \\
12 & $5 / 20$ & $5 / 90$ \\
\hline
\end{tabular}




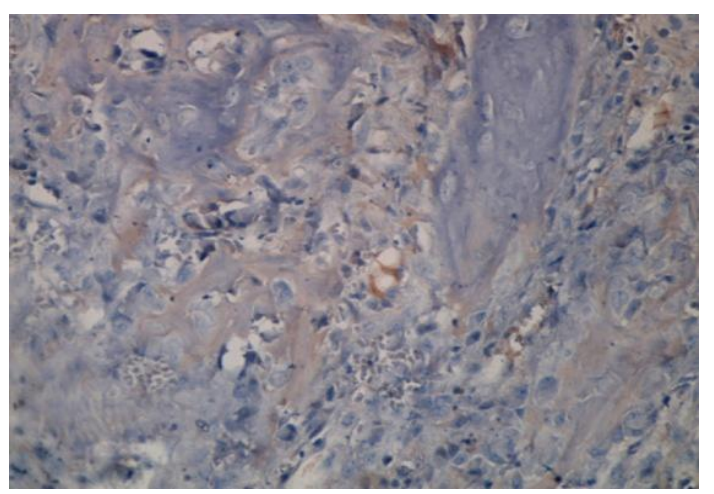

Gambar 3. Gambaran imunohistokimia ekspresi VEGF kalvaria awal. Tampak sel-sel yang mengekspresikan VEGF berwarna kecoklatan, sel progenitor (SP), dan sel endotel (SE)

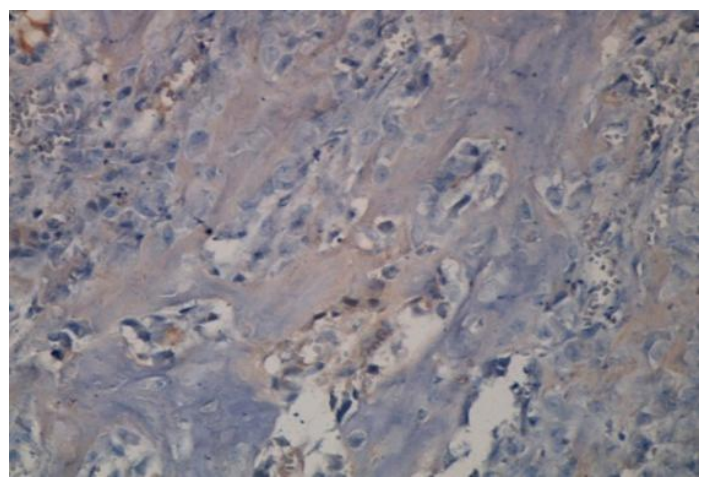

Gambar 4. Gambaran imunohistokimia ekspresi VEGF kalvaria setelah 3 minggu pada kelompok kontrol, tampak sel-sel yang mengekspresikan VEGF berwarna kecoklatan.

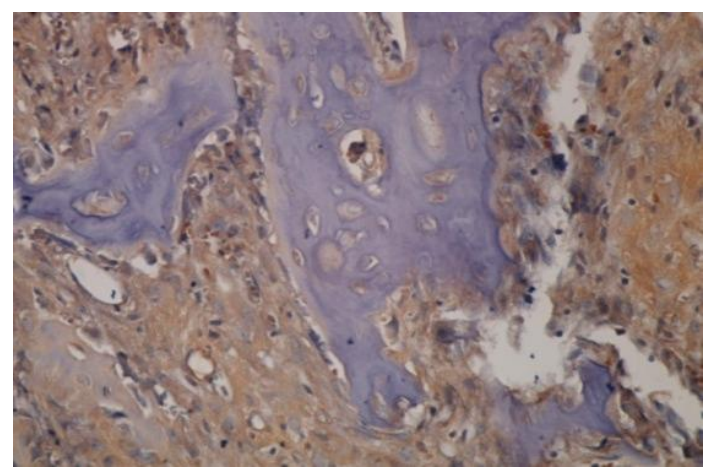

Gambar 5. Gambaran imunohistokimia ekspresi VEGF kalvaria setelah 3 minggu pada kelompok perlakuan, tampak sel-sel yang mengekspresikan VEGF berwarna kecoklatan

Oleh sebab itu, perbedaan antara kedua kelompok dilanjutkan dengan uji MannWhitney yang menunjukkan tidak terdapat perbedaan nilai VEGF awal antara kelompok kontrol dan kelompok perlakuan
$(P=0,311)$ dan terdapat perbedaan nilai VEGF akhir antara kelompok kontrol dan kelompok perlakuan $(P<0,0001)$. Berdasarkan hasil tersebut maka dinyatakan bahwa terdapat perbedaan bermakna antara ekspresi VEGF defek kalvaria kelompok kontrol terhadap kelompok perlakuan yang yang diberikan plasma kaya trombosit dan karbonat apatit.

\section{BAHASAN}

Berdasarkan hasil penelitian ini tampak bahwa ekspresi VEGF awal kedua kelompok hampir sama sedangkan ekspresi VEGF akhir kelompok perlakuan lebih tinggi dari kelompok kontrol. Nagata et al. ${ }^{9}$ juga telah melakukan penelitian pada defek tulang kepala tikus dengan pemberian rasio plasma kaya trombosit yang berbeda selama 30 hari. Pada penelitiannya, Nagata mendapatkan bahwa ekspresi VEGF dan regenerasi tulang paling baik tampak pada pemberian plasma kaya trombosit terutama dengan rasio yang tinggi.

Hasil pemeriksaan imunohistokimia VEGF jaringan tulang kalvaria awal memberikan gambaran ekspresi VEGF yang positif. Ekspresi VEGF tersebut ditunjukkan oleh sel-sel progenitor dan sel endotel yang berwarna kecoklatan. Hal ini menunjukkan bahwa VEGF berperan pada proses angiogenesis dan osteogenesis yang diperlukan dalam fisiologi normal tulang. Peranan ini juga dinyatakan oleh Gerber et al. ${ }^{10}$ bahwa VEGF berperanan pada pertumbuhan kapiler dan pembentukan tulang. Tiga aktivitas pokok sel endotel dalam angiogenesis yaitu sekresi protease, migrasi, dan proliferasi. VEGF mampu memicu ketiga proses tersebut dan bekerja secara spesifik pada sel endotel. Telah jelas bahwa VEGF merupakan kekuatan utama di balik pembentukan semua pembuluh darah. Ekspresi VEGF positif juga ditunjukkan oleh sel-sel progenitor yang merupakan sel unipoten yang bersifat klonogenesis (dapat memperbaharui diri), proliferatif, dan dapat berdiferensiasi menjadi sel dewasa. Sel ini ditemukan pada permukaan tulang di lapisan dalam periosteum, endosteum, dan dalam saluran 
vaskuler dari tulang. Sel ini dapat berproliferasi menjadi osteoblas dan osteoklas. Gambaran ini juga ditunjukkan oleh Athraa et al. ${ }^{11}$ dalam penelitiannya. Athraa et al. menjelaskan secara histokimia adanya ekspresi VEGF awal oleh sel progenitor dan sel endotel yang diikuti pembentukan osteoid dan diferensiasi osteoblas pada minggu pertama, munculnya trabekula tulang pada minggu kedua, serta adanya tulang matur pada minggu keempat.

Pada pemeriksaan imunohistokimia setelah 3 minggu tampak ekspresi VEGF kelompok kontrol antara 20-40\%. Ekspresi VEGF positif ditunjukkan oleh sel progenitor, sel endotel, fibroblas, osteoblas, dan osteosit yang berwarna kecoklatan sedangkan pada kelompok perlakuan tampak ekspresi VEGF sebesar 60-90\%. Hal ini juga diungkapkan dalam penelitian Li et al. ${ }^{12}$ bahwa ekspresi VEGF tertinggi pada proses penyembuhan tulang terjadi antara hari ke-14 hingga hari ke-21. Enas dan Alhijazi ${ }^{13}$ juga menilai ekspresi VEGF pada hari ke 3, 7, dan 10 dan mendapatkan tingginya ekspresi VEGF dengan pemberian VEGF eksogen. Enas dan Alhijazi $^{13}$ juga melaporkan peningkatan osteoblas 2 kali lebih banyak pada pemberian VEGF eksogen.

Penelitian ini menggunakan VEGF eksogen yang terdapat dalam plasma kaya trombosit pada defek tulang yang dihubungkan dengan kemampuannya untuk menggabungkan angiogenesis dan pembentukan tulang. Dalam hal ini, VEGF bertindak sebagai mediator utama terhadap faktor-faktor lain pada proses penyembuhan tulang. Hal ini pernah dibuktikan oleh Yee et al. ${ }^{14}$ yang mendapatkan kalus yang yang dihasilkan lebih tebal pada kelompok yang menggunakan VEGF eksogen. Yee et al. ${ }^{14}$ juga menunjukkan adanya sel-sel inflamasi, sel osteoprogenitor, kondroblas, kondrosit, osteoblas, osteoklas, serta fibroblas yang lebih baik pada minggu ke-4. Pada penelitian ini juga tampak adanya osteoid yang lebih banyak pada kelompok yang diberikan plasma kaya trombosit dan karbonat apatit yang digambarkan dengan pembentukan jaringan osteoid pada daerah defek kalvaria, meliputi peningkatan diferensiasi sel stem menjadi osteoblas oleh VEGF yang melibatkan proses angiogenesis. Rocha et al. ${ }^{12} 5$ berpendapat berbeda yaitu pemberian plasma kaya trombosit tidak memberikan hasil yang bermakna pada pertumbuhan tulang. Hasil penelitian yang serupa juga dikemukakan Miloro et al. ${ }^{5}$ yang mengamati pemberian plasma kaya trombosit pada penyembuhan tulang kelinci dalam 1, 2 dan 3 bulan setelah operasi dan melaporkan pemberian plasma kaya trombosit tidak berbeda bermakna dalam meningkatkan penyembuhan tulang.

Sejalan dengan penelitian Rocha et al. Torres et al. ${ }^{16}$ melaporkan pengaruh plasma kaya trombosit pada regenerasi tulang kepala kelinci selama 2, 4, 6, dan 8 minggu. Torres et al. ${ }^{16}$ menyatakan bahwa regenerasi tulang sama baiknya pada pemberian plasma kaya trombosit maupun kontrol pada minggu ke 2, 6, dan 8 namun pada minggu ke-4 diperoleh regenerasi tulang yang lebih baik pada pemberian plasma kaya trombosit. Penelitian Kim et al. ${ }^{17}$ pada kelinci melaporkan bahwa pemberian plasma kaya trombosit pada defek kalvaria yang dievaluasi setelah 4 dan 8 minggu meningkatkan ekspresi VEGF dan formasi tulang. Bahkan Kim membuktikannya juga dengan evaluasi $\mathrm{X}$ ray dan $\mathrm{CT}$-scan, bahwa densitas tulang lebih baik pada pemberian plasma kaya trombosit.

Pada osifikasi intramembranosa, titik awal osifikasi dimulai bila kelompok selsel berdiferensiasi menjadi osteoblas. Osteoblas berfungsi menyintesis komponen organik dari matriks tulang (kolagen tipe I, proteoglikans, dan glikoprotein). Matriks tulang baru yang terbentuk akan diikuti oleh proses kalsifikasi yang mengakibatkan terkurungnya beberapa osteoblas dalam lakuna yang berada diantara lamela-lamela menjadi osteosit. Dalam hal ini tulang imatur mulai terbentuk setelah minggu ke2. Pada saat itu kolagen tipe 2 dibentuk lebih awal oleh sel osteoblas kemudian membentuk kolagen tipe 1 . Tulang imatur 
tampak sebagai anyaman serat kolagen yang tidak teratur, terdiri dari banyak osteoblas dan memiliki kandungan garam mineral yang sedikit sehingga secara fisik jaringan tulang ini tidak kuat. Diferensiasi sel osteoprogenitor menjadi osteoblas dipengaruhi juga oleh oksigen dan jaringan cedera disekitarnya. Regangan yang rendah serta tekanan oksigen yang cukup mendukung pembentukan tulang imatur. Disini VEGF berperan terhadap pasokan oksigen melalui proses angiogenesis. ${ }^{10,11 \text {, }}$ 13,14

Tulang merupakan jaringan hidup yang kompleks dengan matriks ekstrasel termineralisasi, yang ditandai kekakuan dan kekuatan selama memelihara derajat keelastisannya. Jaringan tulang terdiri atas sel-sel dan matriks organik yang termineralisasi. Matriks organik pada tulang diperkuat oleh deposit dari garam kalsium. Matriks organik pada tulang terdiri dari $95 \%$ kolagen tipe I dan 5\% sisanya tersusun oleh proteoglikan dan sejumlah protein nonkolagen. Adapun garam-garam anorganik yang terdapat di tulang yaitu kalsium fosfat $( \pm 85 \%)$, kalsium karbonat $( \pm 10 \%)$ dan sejumlah kecil kalsium fluorida dan magnesium fluorida. Matriks organik tulang tersebut disintesis oleh osteoblas; proses diferensiasinya ditingkatkan oleh VEGF. ${ }^{10,11,13,14}$

Pada penelitian ini digunakan perancah karbonat apatit yaitu salah satu bentuk mineral yang banyak terdapat pada tulang sehingga penggunaannya bertujuan untuk memicu pertumbuhan jaringan tulang baru yang lebih cepat. Karbonat apatit merupakan perancah komponen anorganik yang identik dengan tulang manusia (karbonat apatit tipe B) dengan struktur porositas 3 dimensi dan memiliki osteokonduktivitas yang sangat baik sehingga mampu memacu pertumbuhan tulang baru dengan cepat. $^{6}$ Dalam penelitiannya, Yoshioka et al. ${ }^{18}$ menyatakan bahwa penggunaan perancah karbonat apatit dan stem sel mesenkim dapat meningkatkan diferensiasi osteoblas dan maturasi tulang.

Pada penelitian ini ekspresi VEGF jaringan tulang lebih baik pada kelompok pemberian plasma kaya trombosit dan karbonat apatit. Hal ini dikarenakan peranan VEGF dalam proses angiogenesis dan osteogenesis, yaitu pembentukan pembuluh darah baru melalui aktifitas sel endotel dan diferensiasi sel progenitor menjadi osteoblas. Gamma-CHA juga sebagai perancah karbonat apatit yang digunakan memiliki kandungan yang identik dengan tulang dan dapat memacu pertumbuhan tulang.

Pada kondisi fisiologik, jaringan tulang tetap mengekspresikan VEGF sebesar 5$10 \%$. Hal ini tampak pada adanya ekspresi VEGF pada sel-sel progenitor dan sel endotel jaringan tulang awal. Terdapat peningkatan ekspresi VEGF jaringan tulang setelah dilakukan tindakan pembuatan defek kalvaria. Rerata peningkatan sebesar 26,67\% pada kelompok defek kalvaria dengan penambahan karbonat apatit dan 80,83\% pada kelompok defek kalvaria dengan penambahan plasma kaya trombosit dan karbonat apatit.

\section{SIMPULAN}

Dari hasil penelitian dapat disimpulkan bahwa terdapat perbedaan bermakna dalam tingginya ekspresi VEGF setelah 3 minggu antara kelompok defek kalvaria yang diberikan plasma kaya trombosit dan karbonat apatit dengan kelompok defek kalvaria yang diberikan karbonat apatit $(P$ $<0,0001)$.

\section{SARAN}

Penggunaan plasma kaya trombosit dan karbonat apatit pada proses penutupan defek kalvaria dapat diteliti pada manusia sehingga diharapkan dapat digunakan sebagai terapi penutupan defek kalvaria.

\section{DAFTAR PUSTAKA}

1. Zhang N, Wu YO, Qian SJ, Teng C, Chen S, $\mathbf{L i} \mathbf{H}$. Research progress in the mechanism of effect of PRP in bone deficiency healing. Sci World J. 2013;2013:1-7. Article ID 134582.

2. Sampson S, Gerhardt M, Mandelbaum B. Platelet rich plasma injection grafts for 
musculoskeletal injuries: a review. Ethics Sci Environ Polit. 2008;(2008): 1-10.

3. Alsousou J, Thompson M, Hulley P, Noble A, Willet K. The biology of platelet-rich plasma and its application in trauma and orthopaedic surgery: a review of the literature. J Bone Joint Surg Br. 2009; 91(8):987-96.

4. Monteiro BS, Del Carlo RJ, Argolo-Neto NM, Nardi NB, Carvalho PH, de Paula Bonfa L. Association of messenchymal stem cells with platelet rich plasma on the repair of critical calvarial defects in mice. Acta Cir Braz 2012;27(3):201-9.

5. Miloro M, Haralson D, Desa V. Bone healing in critical size defect using platelet rich plasma. J Oral Maxillofac Surg. 2010;68(6):1225-30.

6. Van Bergen CJ, Kerkhoffs GM, Ozdemir M, Korstjens CM, Everts V, van Ruijven LJ, et al. Demineralized bone matrix and platelet-rich plasma do not improve healing of osteochondral defects of the talus: an experimental goat study. Osteoarthritis Cartilage. 2013;21:174654.

7. Civinini RMA. The use of autologous blood derived growth factors in bone regeneration. J Clin Case Miner Bone Metab. 2011;8(1):25-31.

8. Elsalanty M, Genecow D. Bone graft in craniofacial surgery. J Craniomaxillofacial Trauma Reconstr. 2009;2(3):125-34.

9. Nagata MJH, Messora M, Pola N, Campos $\mathbf{N}$, Vieira R, Esper L, et al. Influence of the ratio of particulate autogenous bone graft/platelet-rich plasma on bone healing in critical-size defects: a histologic and histometric study in rat calvaria. J Orthop Res. 2010;28(4):46873.

10. Gerber HP, Vu TH, Ryan AM, Kowalski J, Werb Z, Ferrara N. VEGF couples hypertrophic cartilage remodeling, ossification and angiogenesis during endochondral bone formation. Nat Med. 1999;5(6):623-8.

11. Athraa Y, Ahmed DN. Expression of VEGF and BMP7 in bone healing after topical, systemic fluoride application (experimental study in rats). Int Res $\mathbf{J}$ Nat Sci. 2014;2(1):52-68.

12. Li QD, Hang Y, Chang XW, Wei FH. Effect of the timing of surgery on the fracture healing process and the expression levels of vascular endothelial growth factor and bone morphogenetic protein-2. Expo Ther Med. 2014;8(2):595-9.

13. Enas F, Alhijazi AY. Histological and immunohistochemical evaluation of the effect of local exogenous application of VEGF on bone healing (experimental study in rat). J Bagh Coll Dentistry. 2014;26(4):108-14.

14. Yee G. The spatiotemporal expression of VEGF in fracture healing. 50th Annual Meeting of the Orthopaedic Research Society, Poster No: 0472. 2009.

15. Rocha FS, Ramos LMA, Batista JD, Zanetta-Barbosa D, Ferro EAV, Dechichi P. Bovine anorganic bone graft associated with platelet-rich plasma: Histologic analysis in rabbit calvaria. J Oral Implantol. 2011;37(5): 511-8.

16. Torres $\mathbf{J}$. Influence of platelet rich plasma on bone regeneration: a histomorphometric study in rabbit calvaria. $\mathrm{J}$ Oral Maxillofac Implant. 2007;22:563-8.

17. Kim E, Park E. Platelet concentration and its effect on bone formation in calvarial defects an experimental study in rabbits. J Prosthodont Dent. 2001;86(4):428-33.

18. Yoshinoka M, Tanimoto $K$, Tanne $Y$, Awada T. Bone regeneration in artificial jaw cleft by use of carbonated hydroxyapatite particles and mesenchymal stem cells derived rrom iliac bone. Int J Dent. 2012;2012:1-8. Article ID 352510. 